\title{
Methodical and Practical Aspects of the Spatial Development of Ukrainian Regions, Based on Smart-Specializations
}

\author{
Olha Komelina \\ Department of Management and \\ Logistics \\ Poltava National Technical Yuri \\ Kondratyuk \\ Poltava, Ukraine \\ ORCID ID: 0000-0001-9297-4985
}

\author{
Inna Miniailenko \\ Department of Enterprise Economics \\ and Personnel Management \\ Poltava National Technical Yuri \\ Kondratyuk \\ Poltava, Ukraine \\ inna.minyaylenko@gmail.com \\ Andriy Pluzhnyk \\ Department of Management and \\ Logistics \\ PJSC "Poltava-Bank" \\ Poltava, Ukraine \\ ORCID ID: 0000-0002-6526-2613
}

\author{
Anna Komelina* \\ Department of Compliance \\ PJSC "Poltava-Bank" \\ Poltava, Ukraine \\ komelina.anna@gmail.com
}

\begin{abstract}
We have formulated in the article several methodological provisions on the study of the regional spatial development based on smart-specializations. We have justified that the resource and economic components of the region's development are its basis. The authors found that there are conditions for spatial development - interoperability elements in a specific system of spatial coordinates over time, their strategic orientation, ordering, structuring relationships while maintaining the integrity and independence of each element of space. Significant components of the regional spatial development are the development of areas production and services balance these fields, investing new technologies, the diffusion of technologies. We have developed proposals to support the strategic priorities of spatial development and to formulate a regional policy for its provision. We also demonstrated that strategic planning is an essential tool to regulate spatial development systematically. Strategic planning allows combining the economic development forecast and the development of possible scenarios based on the strategies formed and take into account the views of all stakeholders.

Based on the principles of scientific substantiation, consistency, the effectiveness of the state policy of regional development and consistency with the budgetary structure of the country, a conceptual scheme of strategic planning of the regional spatial development based on reasonable specializations and methodological support for its practical implementation has been developed.

The methodology developed by us implies the choice of promising models of the regional spatial development under the influence of changes in resource and investment provision. This methodology involves developing a mechanism for joint financing of regional and interregional programs (projects): formation of better regulatory and legal support for public-private partnerships, taking into account the features of the use of reasonable specializations.
\end{abstract}

Keywords-spatial development, management, strategic planning, priorities, modeling, scenarios, strategies, smartspecializations.
I. AN OVERVIEW OF RESENT RESEARCH SOURCES AND PUBLICATION

Significant structural changes in the economy of Ukraine and its regions and the formation of new poles of spatial development are the result of the influence of many factors. The processes of globalization and European integration, the totality of internal economic and political factors, the redistribution of markets for goods, labor and capital, the transformation of the mechanisms of state and regional governance due to the decentralization reform are the key factors that determine the nature and intensity of economic growth in Ukraine's regions. The practical experience of EU countries shows that the basis for spatial development is to provide synergistic effects to create a comfortable and safe environment for human life. That requires a balance of managerial influences on the formation of regional space and coordination of regional strategies, taking into account the European experience based on smart-specialization.

Many Authors embodied the basic principles of the theory of spatial development in foreign and domestic economic science in the early ' 30 s of the last century. We have identified such Ukrainian scientists and their scientific works.T. Zayats[1] considered the economic aspects of the spatial development of rural settlements and new factors of the formation about "points" of their development in current conditions. N. Parkhomenko [2] researched spatial development in the context of socioeconomic development of the region. N. Pavlikha considered the features of sustainable development management in spatial format and the problem of ensuring the efficient organization of space [3].

O. Ischuk, K. Kravtsiv explored methods of forecasting socio-economic development concerning space change and obtaining a synergistic effect as a result of developing spatial development models $[4,5]$. In Table 1 , we display current nationaland foreign approaches to defining the 
starting points of the theory of spatial development in a generalized way.

\section{TABLE I. GENERALIZATION OF NATIONAL AND FOREIGN} SPATIAL DEVELOPMENT APPROACHES

\begin{tabular}{|c|c|}
\hline Author & The essence of the concept \\
\hline $\begin{array}{l}\text { W. Saled, A. Faludi } \\
{[6,7]}\end{array}$ & $\begin{array}{c}\text { Spatial development is the process of } \\
\text { qualitative change in the organization of the } \\
\text { territory. }\end{array}$ \\
\hline $\begin{array}{l}\text { K. Desmet, E. Rossi- } \\
\text { Hansberg [8] }\end{array}$ & $\begin{array}{l}\text { Spatial development - effective organization of } \\
\text { territory, its important component is the } \\
\text { economic structure of the object of study. }\end{array}$ \\
\hline $\begin{array}{l}\text { A. Lesch "The } \\
\text { Spatial Organization } \\
\text { of the Economy" [9] }\end{array}$ & $\begin{array}{l}\text { Spatial definition of the territory is the } \\
\text { development of "economic landscapes", } \\
\text { particularly the areas formed by market zones. }\end{array}$ \\
\hline $\begin{array}{l}\text { F. Perroux (concept } \\
\text { of the "growth pole") } \\
{[10]}\end{array}$ & $\begin{array}{l}\text { Spatial development - formation of space } \\
\text { around the "growth pole", ie leading industries. }\end{array}$ \\
\hline $\begin{array}{l}\text { J. Boudeville } \\
\text { (growth pole } \\
\text { concept) [11] }\end{array}$ & $\begin{array}{l}\text { Spatial growth poles are territories that have an } \\
\text { effective structure of economic activity through } \\
\text { the introduction of innovation. }\end{array}$ \\
\hline $\begin{array}{l}\text { P. Pottier (concept of } \\
\text { "axes of } \\
\text { development") [12] }\end{array}$ & $\begin{array}{l}\text { The spatial size of the region - a set of poles of } \\
\text { growth, the existence of which are provided } \\
\text { through transport infrastructure. }\end{array}$ \\
\hline $\begin{array}{l}\text { Ratti R. D'Ambrogio } \\
\text { (Three } \quad \text { Space } \\
\text { Theory) [13] }\end{array}$ & $\begin{array}{l}\text { Spatial development consists of production, } \\
\text { market spaces and well-established strategic } \\
\text { relationships with suppliers, consumers, } \\
\text { authorities, and other institutions. }\end{array}$ \\
\hline $\begin{array}{l}\text { K. Bystryakov, } \\
\text { Y. Mantsevich } \\
{[14 \text { p. } 41]}\end{array}$ & $\begin{array}{l}\text { Economic Space - The physical space of an } \\
\text { object and the economic field characterized by } \\
\text { the mutual penetration and intersection of the } \\
\text { object fields. }\end{array}$ \\
\hline T. Pepa [15] & $\begin{array}{l}\text { Spatial development is a complex system of } \\
\text { regional social construction of a country } \\
\text { characterized by both horizontal (regional) } \\
\text { relations and spatial-vertical subordination of } \\
\text { management and management. The system } \\
\text { provides increased socio-economic efficiency. } \\
\text { Spatial development means a set of } \\
\text { organizational measures for managing elements } \\
\text { and connections of territories, a system of } \\
\text { actions. These actions are aimed at optimizing } \\
\text { spatial change. }\end{array}$ \\
\hline $\begin{array}{l}\text { L. Shevchuk, } \\
\text { J. Shevchuk, } \\
\text { S. Shcheglyuk } \\
\text { [16 p. 17] }\end{array}$ & $\begin{array}{l}\text { Spatial development of a region is a change in } \\
\text { the status of economic entities occurring in } \\
\text { geographical space. Changes in economic } \\
\text { activity are characterized by changes in the } \\
\text { interconnections between economic entities, } \\
\text { functions between them, which are manifested } \\
\text { in territorial-structural processes. }\end{array}$ \\
\hline
\end{tabular}

The systematization of scientific approaches to the spatial development of regions makes it possible to draw the following fundamental conclusions for further research:

The basis for the spatial development of a region is its resource and economic components. The land resources is a defining category in geographical, economic, demographic and other contexts;

conditions of spatial development are the ability to interacting elements in a particular spatial coordinate system over a while, their strategic orientation, orderliness, structured relationships while maintaining the integrity and independence of each element of space;

the main factors for ensuring the regional spatial development are the development of products and services, the equilibrium of these spheres, the investment in new technologies, the diffusion of innovative technologies.

The regional spatial development based on smartspecialization should ensure its transition to a qualitatively new state by changing the ratio of the essential components of space and the connections between them. The implementation of this approach requires evaluation, modeling, and scenario forecasting in specific spatial coordinates of crucial components of a region as a system, taking into account all its elements and interdependencies between them[17].

\section{THE MAIN PURPOSE OF THE ARTICLE}

The purpose of the research is to develop methodological and practical approaches to the spatial development of Ukrainian regions based on smartspecialization. Implementation of the methodological approach involves economic and mathematical modeling of the priorities concerning the development of the regional economy and determining their impact on the social and environmental parameters of the region, the choice of optimal scenarios and strategies for the regional spatial development, taking into account the existing constraints.

\section{THE MAIN RESULTS OF THE RESEARCH}

The association agreement between the European Union and the European Atomic Energy Community and their member states, the one part, and Ukraine, the other part provides for developing economic integration. Specialization is a crucial element of cooperation and possible use of European Structural and Investment Funds and the basis of decentralization processes.

Twelve countries have implemented a European approach to formulating smart-specialization strategies at national and regional levels. In Ukraine, at the government level, it is stated that smart-specialization is an opportunity to direct the synergy of science, business, and local selfgovernment into completely new investment perspectives of the regions and bring communities to a new level of development. An innovative system for developing spatial strategies with smart-specialization criteria involves changing approaches to adjusting the structure of the economy, identifying key, structuring types of economic activity based on modeling based on resource and investment constraints, solving social and environmental problems of territorial communities.

The generalization of the basic principles of spatial development management in European countries made it possible to determine the guidelines for the construction of the concept of the spatial development of Ukraine and its regions. These include: achieving the goals of economic and social cohesion; regulation of relations between the authorities; business and communities; conservation of the environment; supporting the development of a knowledge society; secure management of natural resources; management of demographic and migration processes; increase of investment-innovative potential of development; stimulating cooperation between enterprises of related industries within the region in order to jointly implement strategies.

Strategic planning is the primary tool for implementing regional spatial development policy. This is a new useful tool for the implementation of spatial policy, based on the use of innovation and investment potential, allows to form a fundamentally new structure of the region's economy, taking into account new "growth points", to create 
conditions for the development of competitive types of economic activity based on innovation.

Implementation of strategic planning on the basis of smart-specialization in the activity of the regional authorities enables: to identify opportunities for innovative development of the region; to evaluate the resource potential of development by the criteria of smartspecialization; identify alternative ways of achieving the set development goals; assess the investment needs of the strategic and operational goals of spatial development in the region; evaluate the effectiveness of the implementation of selected economic, social and environmental priorities to ensure the regional spatial development.

The strategic planning of spatial development in the region based on the strengths and weaknesses of the regional economy; the main result is the formation and development of new competitive advantages of the region with a focus on creating better living conditions for people; partnership of all regional forces; achieving a higher level of cohesion of territorial communities, business, investors, authorities based on a shared vision of the future development of the territory.

The methodology of strategic planning of theregional spatial development based on the criteria of reasonable specialization includes the following main parts: assessment of the potential of the regional spatial development; development of the concept and scenarios of development of the region on the basis of its sectoral priorities ("poles" of development of the region); selection and substantiation of directions of regional spatial development, creation of strategic platform of the regional spatial development, which fulfills both the information basis of the course of strategic planning and realization of the selected priorities, as well as the basis for reconciling strategic and operational goals of the development of the region, its resources, formation of the budget of participation among all interested parties participants.

The creation of a regional platform for strategic planning of the regional spatial development has. Practical value The Regional Strategic Planning Platform is a tool for establishing partnerships, a mechanism for identifying and implementing practical actions in all spheres of life in the region. The meaningful content of this platform requires the involvement of all stakeholders, including NGOs, regional authorities, academics, and business. That allows defining a shared vision of the regional spatial developmentas a whole that determines the goals of the development of industries under criteria of smartspecializations, to establish ways to achieve the set goals, taking into account potential opportunities, to determine rational ways of using available resources.

Strategic planning for the regional spatial development involves the creation of a competitive economy based on the criteria of reasonable specialization, the creation of innovative infrastructure, stimulation of innovation and investment activity, the identification of a key, structureforming industries. The development of structuring industries will create additional (more worthy) added value chains.
The next stage of strategic planning of spatial development of a region based on defined strategic priorities (goals, objectives, projects) is:

1) development of economic and mathematical models of the combination of different sectoral and component components of the regional economy, which must be based on reliable and verified information, be adequate, meet the mathematical criteria and economic laws;

2) assessment of possible economic, social and environmental effects from the implementation of selected sectoral priorities and their impact on the growth of the gross regional product, population income and reduction of environmental pollution in the region;

3 ) assessing the quantitative and qualitative parameters of the spatial development potential of the region as a whole and in terms of its components (production, labor, investment, innovation, consumer, financial, infrastructure), as well as determining the economic, social, criminal and environmental risks of the regional spatial development.

We propose Regional spatial modeling (RSM) based on the use of the production function and the Lagrange function. That makes it possible to determine the optimal structure of the region's economy based on selected priority economic activities (EA). We anticipate that the implementation of these priorities in the aggregate should maximize the growth of gross regional product (GRP) while utilizing available resource potential and investment opportunities (constraints). This approach allows coordinating the vectors of changes in the regional spatial development in the practical plane [19].

The production function that describes the dependence of the GRP on the production of products in the $\mathrm{i}-\mathrm{th}, \mathrm{j}$-th, and $\mathrm{k}$-th industries is as follows:

$$
Y=a_{i j k} X_{i}^{\alpha_{i}} X_{j}^{\alpha_{j}} X_{k}^{\alpha_{k}}
$$

where $X_{i}, X_{j}, X_{k}$ is the volume of the $\mathrm{i}$-th, $\mathrm{j}$-th and k-th EA in GRP;

$$
\begin{aligned}
& \alpha_{i j k} \text { - constant value; } \\
& \alpha_{i}, \alpha_{j}, \alpha_{k} \text { - coefficients in model of the } \mathrm{i} \text {-th, } \mathrm{j} \text {-th and }
\end{aligned}
$$
k-th EA.

The problem statement determines for which values of $X_{i}$, $X_{j} X_{k}$ the maximum GRP is reached with the constant value of investments $(K)$ in the $\mathrm{i}$-th, $\mathrm{j}$-th and $\mathrm{k}$-th industries and the impact of the investment capacity (R) in the respective industries. This model can be applied to solve the problems of optimizing the investment of strategic EAs based on the calculated ratio of projected increments $\Delta \mathrm{X}_{\mathrm{i}}, \Delta \mathrm{X}_{\mathrm{j}}$, and $\Delta \mathrm{X}_{\mathrm{k}}$ to the projected value of investments (Figure 1).

The developed approach allows forming adequate and reliable models of the regional spatial development, taking into account the structure-forming industries and identified priority EAs, which provide the most significant increase of GRP and are accompanied by social and environmental effects.

Obtained models of the regional spatial development are the basis for constructing scenarios of the regional spatial development. In the present conditions for the 


\begin{tabular}{|c|c|c|c|c|}
\hline 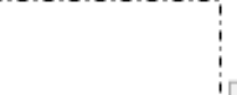 & \multicolumn{4}{|c|}{$\begin{array}{l}\text { The production function that describes the dependence of the GRP on the contribution of the } i, j, k \text { tope of economic } \\
\text { activity is of the following form: } Y=a_{i j k} X_{i}^{\alpha_{i}} X_{j}^{\alpha_{j}} X_{k}^{\alpha_{2}}\end{array}$} \\
\hline \multirow{2}{*}{$\begin{array}{c:}\text { FORMATIONOF } \\
\text { THE OPTIMAL } \\
\text { GRALNEGIONAL } \\
\text { PRODUCT MODEL }\end{array}$} & $\alpha_{i j k}$ is constant & \multicolumn{2}{|c|}{$\begin{array}{c}\alpha_{i}, \alpha_{j}, \alpha_{k} \text { where the coefficients of } \\
\text { the model are the } i, j, k \text { tope of } \\
\text { economic activity }\end{array}$} & $\begin{array}{l}X_{i}, X_{j}, X_{k} \text { is contribution to the } i_{i}, k \text { tope of } \\
\text { economic activity in the GRP }\end{array}$ \\
\hline & \multicolumn{4}{|c|}{$R_{i} X_{i}+R_{j} X_{j}+R_{k} X_{k}=K_{i}+K_{j}+K_{k}$} \\
\hline & \multicolumn{2}{|c|}{$\begin{array}{l}R_{i}, R_{j}, R_{k} \text { capital intensitythe } i, j, k \text { type of } \\
\text { economic actrity }\end{array}$} & \multicolumn{2}{|c|}{$K_{i}, K_{j}, K_{k}$ is investment the $i, j, k$ tvpe of economic activity } \\
\hline & \multicolumn{4}{|c|}{ Lagrange function: $L=a_{j k} X_{i}^{\alpha_{i}} X_{j}^{\sigma_{j}} X_{k}^{\alpha_{j}}+\lambda\left(R_{i} X_{i}+R_{j} X_{j}+R_{k} X_{k}-\left(K_{i}+K_{j}+K_{k}\right)\right) \rightarrow \max$} \\
\hline \multicolumn{3}{|c|}{ ECONOMCAND MATHEMATICAL CALCLIAATION RESUITS } & \multirow{3}{*}{\multicolumn{2}{|c|}{$\begin{array}{l}X_{j}=\frac{R_{i} \alpha_{j}}{R_{j} \alpha_{i}} X_{i} \\
X_{k}=\frac{R_{i} \alpha_{k}}{R_{k} \alpha_{i}} X_{i} \\
X_{i}\left(R_{i}+\frac{R_{i} \alpha_{j}}{\alpha_{i}}+\frac{R_{i} \alpha_{k}}{\alpha_{i}}\right)-K_{i}+K_{j}+K_{k} \\
X_{i}=\frac{\left(K_{i}+K_{j}+K_{k}\right) \alpha_{i}}{R_{i} \alpha_{i}+R_{i} \alpha_{j}+R_{i} \alpha_{k}}=\frac{\left(K_{i}+K_{j}+K_{k}\right) \alpha_{i}}{R_{i}\left(\alpha_{i}+\alpha_{j}+\alpha_{k}\right)} \\
X_{j}=\frac{\left(K_{i}+K_{j}+K_{k}\right) \alpha_{j}}{R}\end{array}$}} \\
\hline \multicolumn{3}{|c|}{$y=0,481717 \times G R P_{\text {mining }}^{0,475487} \times G R P_{\text {const }}^{0.391813} \times G R P_{\text {trans }}^{0.53567:}$} & & \\
\hline \multicolumn{3}{|c|}{$\begin{array}{l}\text { where } Y \text { is GRP taking into account the synergistic effect of the } \\
\text { contribution of extractive industy, construction and transport; } \\
G R P_{\min }, G R P_{\text {esns }}, G R P_{\text {tosx }} \text { is the contribution of extractive } \\
\text { industry, construction and transport in the formation of the GRP, } \\
\text { respectively. }\end{array}$} & & \\
\hline
\end{tabular}

Fig. 1. Method of calculating the optimal gross regional product

regions of Ukraine, it is proposed to develop a realistic scenario, the scenario of stabilization development (with the maximum possible attraction of available investment and resource potentials), the scenario of accelerated development (which implies innovation and investment activity of business, initiation of innovations and reasonable specializations).

The practical implementation of this methodological approach to modeling the spatial development of regions was carried out on the example of the Poltava region. We have revealed that the Poltava region has a considerable financial investment, consumer and production potential, therefore in the further research, it is necessary to concentrate from the point of strategic planning of its spatial development on the study of EAs such as mining, processing, agriculture, wholesale and retail. The development of these industries allows to maximize the potential of the region and formulate strategies for its investment support, but it is necessary to pay attention to the social and environmental component.

The retrospective evaluation of the effectiveness of strategic planning in the spatial development of Poltava region (2000 - 2016) revealed the following: 1) the dynamics and rates of change of the GRP forming as a result of transformation of the structure of its economy and change of the role of structure-forming industries, where In 2019 , mining will account for $35.2 \%$ (12.9\% in 2001), agriculture $26 \%(20.5 \%$, in accordance); there will be a further decrease in the share of processing industry in GRP to $12.7 \%$, although in 2001 - 2008 its share ranged from $26 \%$ to $33 \%$; 2) there is a narrowing of the economic basis of the regional spatial development due to the use of mostly natural resource potential with insufficient involvement of financial, investment and production, which increases the load on the ecological system while maintaining the problem of productive employment of the population; 3) implementation of the European practice of smart-specialization requires changing approaches and introducing new criteria for choosing the economic priorities of the regional spatial development.

Based on multivariate modeling of economic priorities of the regional spatial development, taking into account its available resource-investment potential for the period up to 2023, we propose spatial development strategies and scenarios for their implementation (Table 2).

According to the table. 2 for the Poltava region, we have chosen an adaptation strategy to provide RSM. The economic core is the development of agriculture, mining, wholesale, and retail trade. These industries can provide the right conditions for exploiting the spatial development potential of the Poltava region.

The disadvantages of this strategy are the limited ability to realize the innovative potential of the region and the high likelihood of social and environmental risks.

The model of the spatial development of agriculture, forestry and fisheries, extractive industry and wholesale and retail trade of the Poltava region (as the structureforming EA) in the realistic scenario is as follows:

$$
y=453,599 \times G R P_{\text {agro }}^{0,032933} \times G R P_{\text {min ing }}^{0.240929} \times G R P_{\text {trade }}^{0.301705}
$$

where in GRP is the result of the synergistic effect of the development of agriculture, forestry and fisheries in 
GRP (GRPagro), mining in GRP (GRP $\left.P_{\text {mining }}\right)$, wholesale and retail trade in GRP (GRP trade)

TABLE II. ALTERNATIVE SPATIAL DEVELOPMENT STRATEGIES OF POLTAVA REGION FOR 2019 - 2023 ACCORDING TO DIFFERENT SCENARIOS

\begin{tabular}{|c|c|c|c|}
\hline \multirow{3}{*}{$\begin{array}{c}\text { Criteria } \\
\text { for } \\
\text { selecting } \\
\text { strategies }\end{array}$} & $\begin{array}{c}\text { AdaptiveStrategy } \\
\text { (realistic } \\
\text { scenario) }\end{array}$ & $\begin{array}{c}\text { Stabilization } \\
\text { Strategy } \\
\text { (Stabilization } \\
\text { and } \\
\text { Development } \\
\text { Scenario) }\end{array}$ & $\begin{array}{c}\text { Innovational } \\
\text { and } \\
\text { Investitional } \\
\text { Strategy } \\
\text { (Accelerated } \\
\text { Development } \\
\text { Scenario) }\end{array}$ \\
\hline & \multicolumn{3}{|c|}{ Economic Development Priorities (EA-forming) } \\
\hline & $\begin{array}{c}\text { agriculture, } \\
\text { mining, wholesale } \\
\text { and retail trade }\end{array}$ & $\begin{array}{c}\text { agriculture, } \\
\text { construction, } \\
\text { real estate } \\
\text { operations } \\
\end{array}$ & $\begin{array}{l}\text { agriculture, } \\
\text { mining, } \\
\text { financial } \\
\text { operations }\end{array}$ \\
\hline $\begin{array}{c}\text { Production } \\
\text { potential }\end{array}$ & Significant Level & High Level & High Level \\
\hline $\begin{array}{c}\text { Investment } \\
\text { potential }\end{array}$ & Significant Level & High Level & High Level \\
\hline $\begin{array}{c}\text { Investment } \\
\text { potential }\end{array}$ & Medium Level & Significant Level & High Level \\
\hline Risks & Medium Level & Acceptable Level & LowLevel \\
\hline
\end{tabular}

We substantiate the goals and results of the implementation of the adaptation strategy of the regional spatial development of Poltava region, which is presented in figure 2.

Implementation of the chosen strategy under a realistic scenario will increase the GRP of the Poltava region in 2019 - 2023 by 24444,213 mln UAH. Moreover, it gets additional social and environmental effects, creates high-performing jobs. Increasing population incomes and strengthening decentralization processes will create additional impulses to finance the development of other industries.

Implementation of the stabilization strategy (the scenario of stabilization development) is possible if the activation of innovation-investment activity and liberalization of the land market provided.

The accelerated development scenario (innovation and investment strategy) is the most effective and allows us to obtain the maximum increase of GRP by 115411,999 mln UAH during 2019 - 2023 and create the conditions for a formation of new structure-forming industries, taking into account the criteria of smartspecializations. Implementation of the innovation and investment strategy is possible under the conditions of significant economic growth, improvement of the investment climate, the revival of crucial points of growth of the region's economy.

The gradual implementation of the developed spatial development strategies based on the choice of structural elements of the regional economy (economic nucleus) will increase the level of GRP as a whole, which will influence the increase of employment, the well-being of the population and improve the environmental situation in the Poltava region.

Strategic planning for the spatial development of the region require regulation by law. The realization of the strategic goals of the regional levels is possible only in the presence of a coherent state system of program and forecast documents. These documents include: adopting an RSM strategy; development and approval of baselines and targets for RSM strategic indicators; development of methodological recommendations for creation of a balanced system of indicators of management of RSM; development of methodological recommendations of strategies for reforming and development of regions, taking into account the criteria of reasonable specializations, based on the approach proposed and developed by the authors.

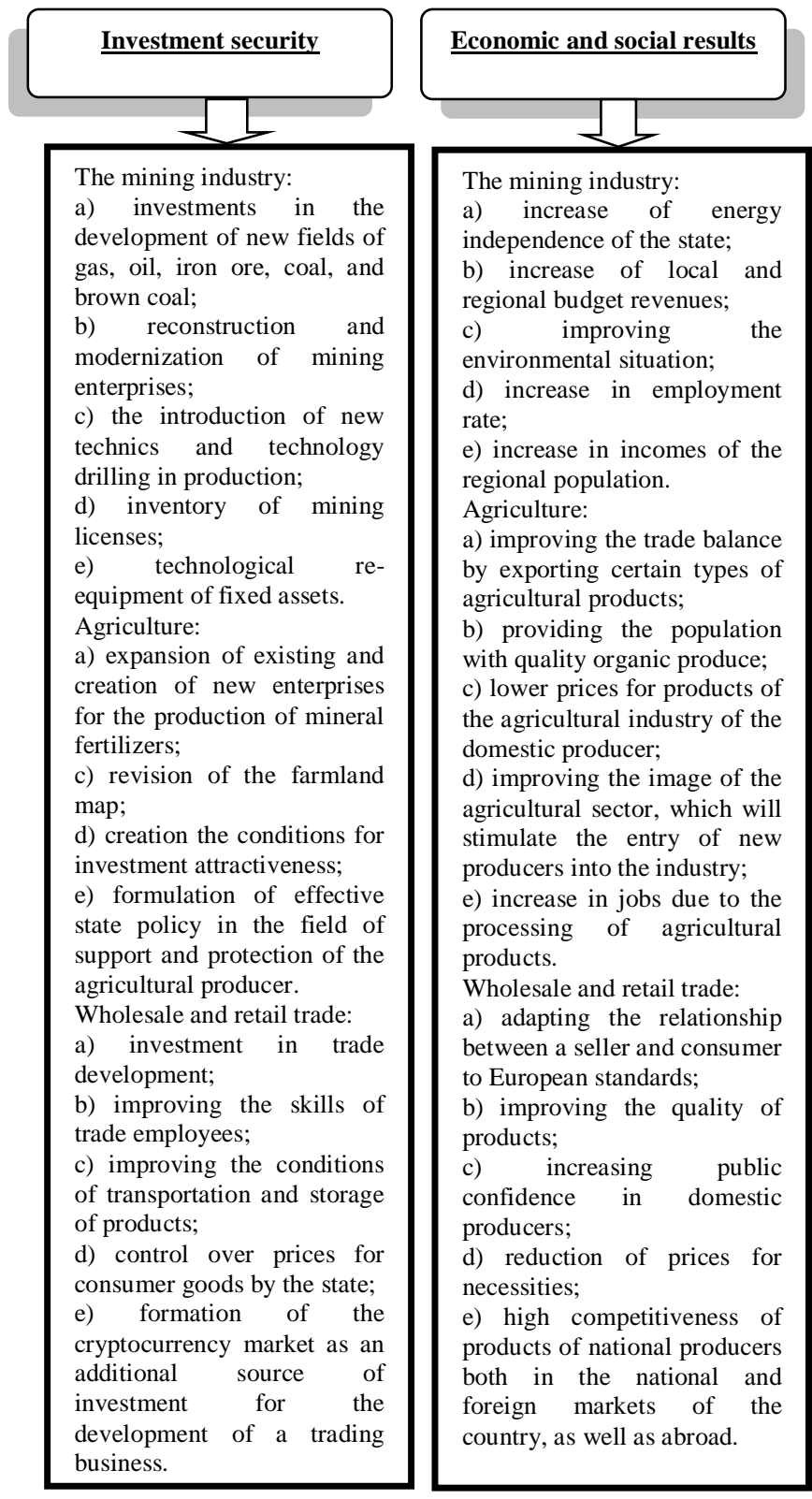

$\Delta \mathrm{GRP}=\mathbf{3 4 0 4 , 7 4} \mathrm{mlnUAH}$

Fig. 2. Strategic Guidelines for the spatial development of agriculture, forestry, fisheries, mining, wholesale and retail in Poltava region

The calculations made on the example of the Poltava region and a well-grounded spatial development strategy for structuring EAs are characterizing by hightech, innovative orientation, environmental security, social orientation, investment attractiveness. All this creates grounds not only for increasing the GRP of the Poltava region but also for increasing the population income, reducing air pollution. 
The implementation of spatial development strategies of the Poltava region will have an impact on increasing population income. What is confirmed by the calculated linkage equation $y=0,5393 x+20567$. The close link between the incomes of the population of the Poltava region and GRP was 0.78 , indicating their high degree of dependence.

We applied correlation-regression analysis to determine the effect of GRP growth on the change in atmospheric emissions, and the following equation constructed at $\mathrm{y}=-2 \mathrm{E}$ $12 x^{3}+6 E-0,7 x^{2}-0,0476 x+1450,6$. Thus, the growth of GRP as a result of the implementation of the developed strategy of the regional spatial development will allow reducing the emissions of harmful substances into the ambient air. The correlation coefficient $(r=0.6)$, which has an average degree of correlation, is a confirmation of the dependence.

\section{CONCLUSION}

The formation of a new model of the spatial development of the Ukrainian economy requires the substantiation of new methodological principles of management, modern approaches and methods of regulation and management of spatial development at the national and regional levels. Regardless of the formulation of the strategic goals of the region for the future, it is imperative to introduce smart-specialization, which will ensure economic growth and increase the competitiveness of the regions.

The proposed methodological and practical approaches to the spatial development of Ukrainian regions based on smart-specializations provide for the implementation of strategic planning methodology. The purpose of strategic planning of the regional spatial development is to develop strategies, that based on simulated modeling, taking into account the resource and investment constraints, the influence of external and internal factors of its functioning [20-21].

The advantages of the proposed methodology for strategic planning of the spatial development of the region are taking into account the existing financial and investment support. That makes it possible to take into account every aspect of all stakeholders in society as a whole, ie, government, business, business, and the united territorial communities.

This approach requires supporting the choice of directions for coordinating the dynamic process of quantitative and qualitative changes in the components of spatial development by taking into account all interrelations.

The main result of the implementation of the developed conceptual scheme of strategic planning is a model of regional spatial development. Implementation requires coordination of all functional services of the regional development management system by taking into account the existing constraints and challenges of the environment, sets of alternative development strategies and adequate actions for their implementation over a long period with an allocation of generally limited financial investment resources [18].

Further challenges require a number of tasks: developing a mechanism for joint financing of regional and interregional spatial development programs (projects); formation of better regulatory and legal support for publicprivate partnership; improving the methodology for selecting investment programs and projects that must take into account spatial development priorities and be consistent with national and sectoral strategies.

\section{REFERENCES}

[1] T. Zayats, G. Kraevskaya, "The Economic Basis of Rural Settlements of Ukraine and Prospects for its Strengthening," Economy of Ukraine., № 9 (650), pp. 70-82, 2016. [in Ukrainian].

[2] N. Parkhomenko, "The Impact of Integration Processes on Regional Socio-Economic Development", Economy and Culture of Ukraine in Global Globalization Processes: Positioning and Realities, Abstracts of the III International Conference. scientific-practical Conf., Kiev, Ed. KNUCiM Center, March 21-22, 2018, 333 p. [in Ukrainian]

[3] N. Pavlikha, "Management of Sustainable Development of Spatial Systems: Theory, Methodology, Experience": Monograph, Lutsk: Volyn Reg. print, 379 p., 2006. [in Ukrainian].

[4] S. Ischuk, E. Boyko, "Forecasting the socio-economic development of the region: issues of theory and methodology", Lviv, 234 p., 2005. [in Ukrainian].

[5] K. Kravets, "Synergistic Effects in Modern Processes of Production Concentration", No. 20, Agrosvit, pp. 44 - 50, 2012. [in Ukrainian].

[6] Willem Salet, Johan Woltjer, "New concepts of strategic spatial planning dilemmas in the Dutch Randstad region", International Journal of Public Sector Management, Vol. 22 Issue: 3, pp. 235-248, 2009. DOI: 10.1108/09513550910949217

[7] Andreas Faludi, "From European spatial development to territorial cohesion policy", Regional Studies, 40:6, pp.667-678, 2006. DOI: 10.1080/00343400600868937

[8] Desmet, Klaus, and Esteban Rossi-Hansberg, "Spatial Development", American Economic Review, 104 (4), pp. 12111243, 2014. DOI: $10.3386 /$ w15349.

[9] A. Lesch, "The Spatial Organization of the Economy", Moscow, Science, 663 p., 2007.

[10] F. Perroux, "L’Economie du XX siècle", P.U.F., 814 p., 1961.

[11] J. Boudeville, "Les'espase economique", Paris, PUF, 1961.

[12] P. Pottier, "Axes de communication et development economique", Revue economique, Vol. 14, Paris, pp.63 - 95, 1963.

[13] R. Ratti, F. D'Ambrogio, "Processus d'innovation et integration locale danc une zone peripherique", Neuchatel: GREMI/EDES, 1993.

[14] K. Bystryakov, Y. Mantsevich, "Problems of Spatial Development of Ukraine from the Perspectives of P. Abercrombie", Economy of Uraine, No 9 (646), pp.39 - 48, 2015. [in Ukrainian].

[15] T. Pepa, "Regional Dynamics and Transformation of Ukraine's Economic Space", Cherkasy: Gate of Ukraine, 440 p., 2006. [in Ukrainian].

[16] L. Shevchuk, J. Shevchuk, S. Shcheglyuk, "Spatial development of Ukrainian regions: theoretical problems and practical tasks", Economist, No.5, pp.17 - 19, 2011. [in Ukrainian].

[17] V. Glazychev, "Russia: principles of spatial development", http://www.glazychev.ru/projects/2004_prostrazv/2004_docladprost razv.htm

[18] O. Komelina, I. Miniaylenko, "Strategic economic orientations for spatial region development", The Advanced Science, issue 9, part 2, pp. $139-143,2014$.

[19] O.V. Komelina, V.V. Vasiuta, I.V. Miniailenko, "Spatial development of construction: modeling and its financial and investment support", International Journal of Engineering \& Technology, 7 (3.2), pp. 183-190, 2018.

[20] D. Foray, P.A. David, B. Hall, "Smart specialisation-the concept", Knowledge economists policy brief, 2009.

[21] N. Komninos, B. Musyck, AIain Reid, "Smart specialisation strategies in south Europe during crisis", European Journal of Innovation Management, 17 (4), pp. 448-471, 2014. 